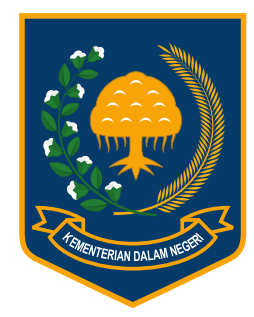

Jurnal Bina Praja 8 (1) (2016): 39-48

Jurnal Bina Praja

e-ISSN: 2503-3360 | p-ISSN: 2085-4323

Accreditation Number

735/AU2/P2MI-LIPI/04/2016

http://jurnal.kemendagri.go.id/index.php/jbp/index

\title{
IMPLEMENTATION OF COMPUTER ASSISTED TEST SELECTION SYSTEM IN LOCAL GOVERNMENTS
}

\author{
Abdul Aziz Basri ${ }^{1, *}$ \\ ${ }^{1}$ Regional Employment Board (BKD) of East Halmahera Regency \\ Jl. Pusat Pemerintahan, Kota Maba
}

Received: 26 February 2016; Accepted: 1 May 2016; Published online: 31 May 2016

\begin{abstract}
As an evaluative way of selection of civil servant system in all government areas, Computer Assisted Test selection system was started to apply in 2013. In phase of implementation for first time in all areas in 2014, this system selection had trouble in several areas, such as registration procedure and passing grade. The main objective of this essay was to describe implementation of new selection system for civil servants in the local governments and to seek level of effectiveness of this selection system. This essay used combination of study literature and field survey which data collection was made by interviews, observations, and documentations from various sources, and to analyze the collected data, this essay used reduction, display data and verification for made the conclusion. The result of this essay showed, despite there a few parts that be problem of this system such as in the registration phase but almost all phases of implementation of CAT selection system in local government areas can be said was working clearly likes in preparation, implementation and result processing phase. And also this system was fulfilled two of three criterias of effectiveness for selection system, they were accuracy and trusty. Therefore, this selection system can be said as an effective way to select new civil servant. As suggestion, local governments have to make prime preparation in all phases of test and make a good feedback as evaluation mechanism and together with central government to seek, fix and improve infrastructures as supporting tool and competency of local residents.
\end{abstract}

Keywords: CAT system, local governments, civil servants

\section{INTRODUCTION}

Global dynamic environments have forced the government to comply in processing all activities, including process of management of human resources. As part of management of human resources, selection has important role to ensure quality and quantity of human resources. In Indonesia process of human resources management particularly in public sector is not show good performance. In fact, working as civil servant in public area has been the most popular profession by almost all residents. It caused government giving a number of strengths to work as civil servant. Such as hard for being faired, flexibility of work mechanism, and certainty for fee pension.

Contrastly, last selection for civil servant system did not support to accommodate the highly desire of resident to be working as civil servant. Last selection system that used paperbased test had several weaknesses namely (1) unstandardized of question making (2) one test for all positions (3) highly risk of infringement because in processing result of the test was not directly (4) disintegrated both of central and local governments selection system. (Ministry of Administrative and Bureaucratic Reform, 2013). As consequence, this condition had created a big chance for corruption, collusion and nepotism grow rapidly.

Recently, condition of Indonesian civil servants was overstaffed and understaffed. Overstaffed involved over quantity in a number of civil servants that in June 2012 reached 4.552 .971 people. Meanwhile, understaffed involved lack of quality and competency that approximately a half of civil servants just senior high school and diploma graduated (Ministry of empowerment for state apparatus and bureaucracy reform, 2012).

Management of civil servants is also a serious problem that not only occurred in central government but also in local government areas. It can be seen by how implementation of civil servant

\footnotetext{
* Corresponding Author

Phone : +62 85240625649

Email : abdulazizbasri94@gmail.com
} 
affair that had transferred to local governments by decentralization mechanism was not working clearly. For example in determining necessity of civil servants that will be filled by selection based workload analysis and position analysis were not calculated primarily. So this fact made another case that approximately all local governments allocated $45 \%$ or 229 billion rupiahs of their Regional Government Budget (APBD) only for civil servants' expenditure. (Ministry of Finance 2011).

Actually, government had tried to fix this problem since 2010 by appointment of President Regulation No 81/2010 about grand design of bureaucracy reform. then it followed by joint regulation of Minister of Administrative and Bureaucratic Reform No 02/SPB/M.PAN$\mathrm{RB} / 8 / 2011$, Minister of Home Affairs No 800632 Tahun 2011and Minster of Finance No 141/ PMK.01/2011 about temporary closing of selection for civil servant, as way to reform and to rearrange condition of civil servants. The government also had tried to make a change despite not in all areas. One of them was appointment of passing grade despite selection system still in conservative mechanism. Besides, all phases of test were done objective, transparent, and fair to reduce several infringements. In implemented the test simultaneously that held on September 8 2012, Committees of selection were made from (1) National Committees including KemenPANRB, National Civil Agency (BKN), BPKP, Consortium of 10 State Universities, National Crypto Agency (Lemsaneg),National Intelligent Agency (BIN), State Ministry for Research and Technology (BPPT), POLRI dan Indonesian Corruption Watch (ICW) (2) Instance/Local Committee.

In 2013, government launched a new system for civil servant selection. That system named computer assisted test (CAT). This system includes two type of tests were basic competency test (TKD) and field competency test (TKB). Basic competency test (TKD) contained three sub-tests were, (1) test of nation acknowledgment (2) test of basic intelligent and (3) test of personal characteristic. For field competency test (TKB) will be adjusted of necessity of positions and works. CAT system was implemented in combination system (Computer Assisted Test and Paper Based Test) with a rate of passing grade. In this case, 84 Central and Local government (51 Ministries/ CentraInstances, 8 Provinces and 15 Cities/Regencies) were chosen selection for their civil servants with computer assisted test. They argued that this system provides several strengths such as in processing result of the test that more transparent. Result of CAT test was reported by BKN to Ministry of Administrative and Bureaucratic Reform and then was distributed to each instance. This result also was used to determine candidates who will be following field competency test. For instance, who applied paper based test, test was held in September 3, 2013. This system was applied to general candidates and honorary candidates (Second Category). Totally 256 instances (21 Ministries/Central Instances, 15 provinces, and 220 Cities and Regencies) for general candidates and 37 Ministries/Central Instances, 33 provinces and 477 Cities and Regencies for honorary candidates had applied paper-based test to select new civil servants. (Profil of Ministry of Administrative and Bureaucratic Reform 2014).

Computer assisted test was implemented for all central and local government instances in 2014 based Minister of Administrative and Bureaucratic Reform regulation No17/2014. Process of selection starts when the candidates make a registration in Panselnas' website and ends when announcement of result of the test.

To support this system, National Civil Agency (BKN) had improved ability of Panselnas' portal to accommodate all candidates, data registration recorded that 1,6 Million candidates had accessed with the highest point in 500 Thousand candidates in a day. (National Civil Agency, 2014).

Process of selection starts when the candidates make a registration in Panselnas' website and ends when announcement of result of the test. in registration section, candidates have to make registration more than one time with only one chance. Then they argued that this procedure was so hard to understand and it was not appropriate for them. As consequence, a high number of candidates were failed sharply in this section. For example, in Ministry of Administrative and Bureaucratic Reform only 1.253 candidates who passed the first registration from 6.528 candidates who accessed and registered in Panselnas' website.

In registration section also, candidates were given three choices of positions in only one local or central government instance in all Indonesian areas. This rule created borderless opportunity for all candidates to work everywhere. Number of candidates decided to work in developed area which level of passed the test was more high. As consequence, local candidates felt that this system decreasing their chance to work as civil servants in their area.

Passing grade as way to measure competency of candidates also considered too hard particularly for them in backward areas. In addition, every candidate has to reach minimum score of each test. As consequence, a high number of candidates failed in this phase and also made few positions were not filled. For example in Ternate City only 104 positions who passed the test from totally 146 required positions. Similarly in East Halmahera from 130 positions only 83 positions who filled. (Ministry of Administrative and Bureaucratic Reform 2015). 
Main characteristic of this system was using advanced technology and requires internet network and it was seen not considered condition in all areas. In 2013, National Statistic Agency (BPS) noted only 71.19 million residents or $28 \%$ of total Indonesian residents who use internet network. Generally, this one of several limited conditions was occurred in backward areas. State Ministry for Acceleration and Development for Backward Regions published through Government Regulation No 78/2014 there are 122 backward regencies/cities within highest rank in eastern Indonesia area such as Papua, Nusa Tenggara, Sulawesi, Maluku, then followed by western Indonesia are Sumatra and Kalimantan in lowest rank. While for Java and Bali, they only have totally 6 backward areas.

In the other hand, if few cases above is being compared with the essential theory, this kind of selection provides few advantages to government. It cause process of online registration is not need long time to identify all applicants and also is more accessible. selection for administrative and professional positions which usually have more stringent education and experience requirements is important to have preestablished criteria. And use multiple screening procedures to pare down the number of candidates. The first screening by who do not meet the minimum requirements and the second screen might eliminate applicants who lack the requisite experience (Pynes, 2009). But In formulate this system, government should realize that not all candidates may have ready to access computers.

A selection system that contained effective and combination types of selection are appropriate for complex and importance positions. Moreover, in process approximately all government activities as consequence of decentralization, local governments need adequate background in appropriate aspects of civil servants. A number of studies earlier have verified and showed that competency of apparatus have highly influence in processing government activities (Kertapraja, 2010).

Recently, a number of studies of this CAT selection system in central and local government areas showed that this system was working clearly. As addition, former Minister of Administrative and Bureaucratic Reform, Azwar Abubakar claimed that the advantages CAT system was overweight to disadvantages, one of them was this system saves almost 600 billion rupiah. ( Layanan Publik Magazine, 2014).

Based all conditions above, this essay has main purpose to describe implementation of selection for civil servant based computer assisted test in local government, then identify effectiveness of this test as conclusion.

\section{METHOD}

\section{A. Management of Human Resource}

Human resources management (HRM) is the design of formal systems in an organization to ensure the effective use of employees' knowledge, skills, abilities, and other characteristics (KSAOCs) to accomplish organizational goals. HRM concerns the recruitment, selection, train- ing and development, compensation and benefi ts, retention, evaluation, and promotion of employees, and labormanagement relations within an organization. In public and nonprofit agencies, the greatest expenses and the greatest assets are employees. Unlike many for-profit organizations, which can use technology to automate the production of their products and reduce staff, public and nonprofi t organizations typically provide some type of service. Thus, they rely on the professionalism and competence of their employees.

Machines cannot be substituted for most public and nonprofit employees. As a result, public and nonprofit agencies are labor intensive; employee costs are typically between 50 and 80 percent of their budgets (Cascio \& Boudreau, 2008; Fitzenz, 2000). Employees are also the greatest assets of public and nonprofit organizations. Whether referring to top leader- ship, department directors or managers, or first-level employees, the quality and competencies of the workforce differentiate successful agencies or departments from others. Why is one police department more effective than another when dealing with similar problems and situated in local governments with similar incomes and demographics and with similar responsibilities? Why is one substance abuse treatment center more effective than another if they are using similar clinical protocols and techniques and have clients with similar problems? The answer is likely to be related to the professionalism and competencies of their employees. The study of HRM has existed for a long time, despite having different names. Frederick Taylor's scientific management addressed the principle of breaking job positions down into their simplest tasks. Scientific management was concerned with production efficiencies through making the best employee and job match. It also addressed employee motivation by developing incentive pay systems. (Pynes, 2009)

\section{B. Concept of Effectiveness}

Effectiveness of a program or work performance can be seen by two approaches, they are, goal approach and system approach. The goal approach to effectiveness consists of identifying an organization's output goals and assessing how well the organization has attained these goals. This is logical approach because organization do try 
to attain certain levels of output, profit, or client satisfaction. The goal approach measures progress toward attainment of those goals. Meanwhile for system approach is how ability of an activity or work performance can grab all system substances completely such as input, process, output, benefit and keep the stability and balance. This approach also applied mainly for important of adapting to external pressure as criteria of effectiveness. (Silalahi, 2011).

\section{Research Framework}

In explaining implementation of CAT selection system in local governments, this essay used combination of theory from V. Rivai in the effectiveness of selection system and Minister of Administrative and Bureaucratic Reform Regulation No. 17/2014.

Rivai shared three aspects as criteria of effectiveness of selection system. They are accuracy, equality and trusty. Accuracy involves how a selection system can working clearly and completely in determining quality and quantity of employees. Equality involves how a selection system gives equal opportunity in all candidates. And trusty involves how process of system selection is accepted for all candidates, include for them who failed the test (Rivai, 2013). In other place, Bethel-Fox adding cost of operating selection system as criteria for effectiveness. This means an effective selection system must be cost-effective so that the time and money spent on it design and administration is justified by the quality of the new requires who are hired. (Alain, 1992).

In Minister Regulation No. 17/2014 had appointed passing grade as tool to measure competency and skill of candidates. for TKD test, every candidate has to reach minimum score for each test.

For field competency test (TKB), result of the test will be scoring in 0-100. In determing result of selection for instances who implemented both of the test were based of highest rank that taken by proportion of $60 \%$ of TKD and $40 \%$ of TKB. And for instances who only implemented TKD test, result of the test was taken by highest rank in each position.

Table 1.

Passing Grade of Basic Competency Test (TKD) 2014

\begin{tabular}{ccc} 
TEST & CRITERIA & MINIMUM SCORE \\
TKP & $\begin{array}{c}72 \% \text { of } 175 \\
\text { (35 Questions) }\end{array}$ & 126 \\
\hline TIU & $\begin{array}{c}50 \% \text { of } 150 \\
\text { (30 Questions) }\end{array}$ & 75 \\
\hline TWK & $\begin{array}{c}\text { 40 of 175 } \\
\text { (35 Questions) }\end{array}$ & 70 \\
\hline
\end{tabular}

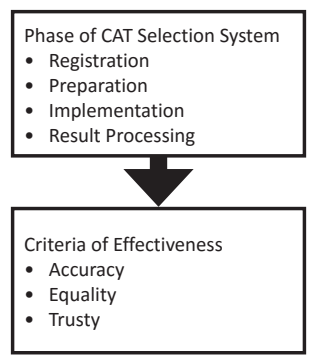

Figure 1. Research Framework

This essay used combination of study literature and qualitative-descriptive approach with the consideration that, this is most appropriate approach for studies that seek to understand and to describe phenomenon (Patton, Ahmadi, 2014). This approach emphasize how importance to collect data naturally. Qualitative models provide ways to discerning, examining, comparing, contrasting and interpreting meaningful patterns or themes. Meaningfulness is determined by particular goals and objectives of project at the hand. The same data can be analyzed and synthesized from multiple angles depending on the particular research or evaluation questions being addressed (Miles and Hubberman, 1994).

This essay used three main tools in collect data were interview, observation, and documentation. (Sugiyono, 2009) Where this essay used documentation as primary data, in this case, study literature as main tool. Data sources were from official report, official website, national media, scientific journals and others. Beside, Interview and observation were not being ignored. For interview and observation had done in apprenticeship for few weeks in Minister of Administrative and Bureaucratic Reform in January 2015.

As addition, triangulation was added as supporting data collection. This tool has main function as to seek deviation, convergent, inconsistency, or contradiction of collected data (Mathinson, Sugiyono, 2009).

In determining person/place as sources data, this essay used purposive sampling, which in choosing sample data was conducted as most know of the research theme (Sugiyono, 2009). for interview was chosen a number of person as informant and represented various sides such as Panselnas, Minister of Administrative and Bureaucratic Reform, Candidates, central and local selection committees. Meanwhile, for documentation, few central and local government were chosen to represent level of government. Main purpose to choose a number of areas was as to compare in implementation of CAT system. Ministry of empowerment for state apparatus and bureaucracy and few regional office of National civil agency (BKN) represented central government. For local government was divided into two areas were 
Advanced areas and develop area.s. D.I Yogyakarta and Samarinda represented advanced regions and West Halmahera, East Halmahera, North Maluku represented develop regions.

The researcher used Minister Regulation No $17 / 2014$ to classify different stages as part of CAT selection, were as followed (1) Basic competency test, include several phases such as registration, preparation, implementation, and processing of the result. Then result of research were being involved within theory of effectiveness of selection.

As critical phases in qualitative studies, data analysis is using to understand relation between concept and collected data in order hypothesis can be developed and evaluated (Stainback, Sugiyono 2009). This essay used Miles and Hubberman (Miles and Hubberman, 1994) model in analysis collected data. They were,

\section{Data Reduction}

Data reduction refers to the process of selecting, focusing, simplifying. Abstracting and transforming the data that appear in written up field notes or transcriptions. Not only do the data need to be considered for the sake of manageability, they also have to be intelligible in terms of the issues being addressed.

\section{E. Display}

Data Display goes a step beyond data reduction to provide organized, compressed assembly of information that permit conclusion drawing. A display can be an extended piece of text or a diagram, chart, or matrix that provides a new way of arranging and thinking about more textually embedded data.

\section{F. Conclusion Drawing and Verification}

Conclusion drawing involves stepping back to consider what the analyzed data means and to assess their implications for the question at hand. Verification, integrally linked to conclusion drawing, entails revisiting the data as many times as necessary to cross-check or verify these emergent conclusions. The meaning emerging from the data have to be tested for their plausibility, their confirmability, that is their validity.

\section{RESULT AND DISCUSSION}

\section{A. Revision in Process of Determining Formation}

Process of determining of formations started and made from job and workload analysis in each government instance to produce detail, map, competency, qualification of positions and to count necessity of civil servants in each positions accorded organization's workload. Every instance also make a necessity of civil servants for 5 years ahead. After formations of civil servants were finished, every instance sent these data in soft copy to propose a number of positions and all requirements who verified by take caring of civil servant affair to Minister of Administrative and Bureaucratic Reform and as copy mechanism to Head of National Civil Agency. Then Minister was given a confirmation involve formation of civil servants that would be filled, and this decision could not to change.

Allocation for formation of positions in 2014 was based growth in national scale. It means number of allocation was more high than number of civil servant who would be pension in 2014. In allocation for instance's formation was used three approaches, they were minus growth, zero growth, and growth. Minus growth was means a number of allocation for formation was more fewer than a number of civil servant who would be pension. This minus growth was used for instances who had overload of civil servants, ratio of civil servant's expenditure more 56\% in Regional Government Budget (APBD) of regency/city, and for province who ratio of civil servant's expenditure more $30 \%$ in Regional Government Budget (APBD). Zero growth was means a number of allocation for formation was similar with a number of civil servant who would be pension. Zero growth was used for condition of civil servant was balance within instance's workload, ratio civil servant's expenditure in scale $40-56 \%$ in Regional Government Budget (APBD) of regency/ city and for province who ratio of civil servant's expenditure in scale 25\%-30\%. Whereas growth was means a number of allocation formation was higher than a number of civil servants who would be pension. Growth approach was used for instance who a number of civil servant fewer than workload, ratio civil servant's expenditure was fewer than $56 \%$ in Regional Government Budget (APBD) of regency/ city and for province who ratio of civil servant's expenditure was fewer than $30 \%$.

Allocation for formation civil servants in 2014 was priority for specific and selective candidates who could give contribution in national development, for impermanent doctor (PTT) who work in government areas, particularly in isolated, backward and uninterested areas and also for technical/functional specific positions.

These several functional positions who be priority in selection for civil servants in 2014, they were:

a. Technical man for functional position as implementor of main function of organization;

b. Positions who would be supported to national development;

c. Positions who could be followed by all education, in 5\% from all allocation for 
formations in each instance;

d. Positions who matched by necessity of instance for residents from Papua;

e. Positions for bachelor who will be working in borderline and backward areas (SM3T);

f. Positions for disability, for example, computer and call center operator;

g. Positions for good athlete and certificated coach;

h. Positions for man/woman who graduated in University who has A accreditation and also A accreditation for Programme Study.

Positions in 4-8 were for Ministries/ Central instances's formation.

Based Minister of Administrative and Bureaucratic Reform Regulation No. 17/2014, Basic Competency Test (TKD) was using computer assisted test to measure basic competency of civil servants and field competency test (TKB) was adjusted necessity of positions.

\section{B. Implementation of CAT Selection System \\ 1) Registration Phase}

At beginning registration phase, candidates were asked to complete several data through online procedure in Panselnas' website. Types of data such as full name, born place and date, NIK, email address, and also three choices in only one instance, to get username and password who would be sent by email. This username and password would be using to access next site registration (sscn.go.id) as confirmation way to each instance. In addition, every candidate only given one chance to register in Panselnas' website. In other hand, these rules made a number of candidates failed sharply in this phase. And online procedure was be the main problem and inhibit factor for candidates in few local areas particularly in developed areas, where internet network was inadequate.

In fact, the only one chance for candidates and online procedure in CAT system were a way who taken as a evaluative policy from implementation of CAT selection system in 2013. At that time, there was a double candidates in several instances, because every candidate was given unlimited chance to follow selection of civil servants everywhere. As consequence, many positions were not filled, because some candidates were passed and accepted in all instances. This case also made some instances decided to fill several positions within under quality of candidates. Meanwhile, main purposes of online registration were as integrated selection system between central and all local governments and also to improve criteria of civil servants particularly in technology. Despite this online registration was under seriously consideration to implement in all areas, government decided and argued that 2014 was the perfect time to apply this new system.

As integrated system, single window registration procedure made all candidates have to access Panselnas' website (panselnas.menpan. go.id) and fill all required data. But in the beginner time of announcement had published, server of Panselnas' website was inadequate to process all data and often server of Panselnas' site was down while candidates filled data. But for this problem Panselnas had given solution through 24 hours call center. Link of Panselnas' call center was available and also linked in Panselnas' website or candidates could come directly to Panslnas's secretary in building of Ministry of Administrative and Bureaucratic Reform. For this case, candidates who completed all required data, could access their email to check username and password to access next site registration, with the consideration that all filled data were not invalid. And for candidates who not completed required data, they just need to refresh Panselnas' website and refill all required data.

Generally, a high rate of failure caused by the candidates were not completely understood the procedure and they filled all requires data inaccurately. For instance, a number of candidates had problem within their number of identification (NIK) card as one of required data. NIK was used as single identity number which as mechanism to ensure all candidates registration in only one instance. In this case, some candidates failed in registration phase because they could not used their NIK with some reason such as invalid NIK, and some NIK of candidates had registered by other people (family/friend). Besides, some candidates decided to not follow next registration phase of selection. It caused announcement in Panselnas' website for instances and positions who would be filled by selection was not published togetherly in all government instances. this made some candidates felt anxious and then choose other instances. They expected that if had registered in one instance, they could move to other instance that be their choice before.

\section{2) Preparation}

In fulfill all necessities for CAT selection system, local governments were helped by teacher competency test system for CAT. This system was available in all areas. This system also as simplicity way for candidates in local areas who followed selection for central government instances. and also local committees have to make coordination with regional offices of National Civil Agency (BKN) or LPMP to ensure process of selection would be working clearly.

Basic competency test for selection of civil servants in 2014 was facilitated by National Civil Agency (BKN) within computer assisted test system 
and Ministry of Education and Culture within teacher competency test system for CAT. UKG-CAT system was shared in all government areas, so most local governments were using this system.

To use CAT who facilitated by BKN, central/ local instances should send letter of asking to head of National Civil Agency (BKN). This as confirmation way to arrange schedule, time, and place of test will be held. After accepted confirmation by BKN, all next stages such as distribution of test questions, scheme of test, installation of database and CAT system will be handled by team CAT BKN. All stages of preparation will work completely with one main conditional thing it was instances fulfill all supporting tools based specification of BKN.

For computers as main supporting tools in central and advanced governments, it was not be serious problem. Every government instance/school has adequate computer facility. But for developed area, it was difficult to adjust within a number of candidates. As consequence, local committees divided schedule for test into few days. Human resources also be a problem for few developed areas. As new modernized system, CAT selection system was not have to understand by candidates but also for local governments as local committees. Despite, most of local civil servants are understand to process computers and another technology, they are not shared prevalently in each local instance.

Selection for civil servant in 2014 was free of cost for all candidates in all government instances. funding source for central government instances from Budget Implementation Registration Form (DIPA) each instance, and for local government were from Regional Government Budget (APBD). Whereas, for operational of National Committee of Selection (Panselnas) funding source was from DIPA of Ministry of Administrative and Bureaucratic Reform.

\section{3) Implementation}

Before followed the test, candidates should pass verification procedure by showed they Identification Card (KTP) and Candidate Identification Card (Kartu Peserta). then Committee read order of the test in the front of candidate in every section of the test. Candidates also given a chance to try CAT system in 30 minutes, in order to understand all the features system and to avoid mistake and also confusion. In the room of test, candidates were prohibited to use mobile phone and left they all belongings in outside of test room.

Candidates should use they number of test given by committees (NIK) to access CAT test system, then candidates would got a number of randomized questions. In 90 minutes, all candidates have to answer totally 100 questions divided into 35 questions test of nation acknowledgment (TWK) 30 questions of test of basic intelligent (TIU) and
35 questions test of personal characteristic (TKP). Control mechanism was only did by team CAT from BKN or LPMP. If a problem occurred in the middle of the test, for example, server system down or others, candidates will be rescheduled to follow the test in other sections.

After finished the test, result of the test would be showed by click finish button on the system. So, all candidates could see a number of point that had reached. but candidates have to wait for processing result and it will be announced by Panselnas.

The TKD questions were made from consortium of several state universities that made and launched by ministry of education and culture. The questions also were made and divided into several level of graduations arranged by necessity of positions. Commonly, for senior high school graduated, Bachelor graduated and Master graduated.

Passing grade for CAT selection of civil servants in 2014 was increased. But the increasing only occurred in side of test of personal characteristic (TKP), from 105 (60\% of totally 35 questions) to 126 (72\% of totally 35 questions). And for both of test of basic intelligent (TIU) and test of national acknowledgment (TWK) had no changed, in rate 75 for TIU and 70 for TWK.

Both of these aspects, level of difficulty of questions and passing grade were be another problem, particularly in developed area. Some candidates argued that the given questions were too hard and similarly for passing grade was too hard to reach. So, there a number of positions were not filled because none candidate who pass the passing grade. In the other hand, former Minister of Administrative and Bureaucratic Reform explained that for some local government instances level of difficult of questions and passing grade were decreased from standard, but there was no changed in the result of test. As Addition, candidates in developed area were difficult to find book and software as way to improve skill in surface CAT test. Contrastly, candidates in advanced areas could easily find software, training book or other kinds to understand, to try, and also being familiar with all features and type CAT of questions. All training book area available in bookstore and for software it can be downloaded from internet.

\section{4) Result Processing}

Result of the test could be seen directly in every candidates's computer and in a big monitor who had prepared by committee in one particular room. Then result of the test was sent to Panselnas by online system. in this case, Panselnas have to make verification after processing the result. Verification mechanism by result of test was printed into 3 pieces with specific colors to use in 3 different receivers. One piece was printed in white paper, for instance, one piece was printed in red paper for Panselnas, 
and one piece was printed in yellow paper for BKN. Beside that, this mechanism also a way to prevent frauds would be occurred.

Panselnas had assumed that time for process result of the test would be spent only one week. Process was started from Panselnas accepted the result, processing, and printed the result in 3 pieces. In fact, Panselnas was announced the result of all stages of test including field competency test (TKB) nearly 4 months. It caused by result of test would be launched at all instances. For instance, who implemented both of TKD and TKB, result of TKD was announced directly after Panselnas had processed the result. It caused TKD was used to determine candidates who will follow TKB test. Meanwhile, for instance, who only implemented TKD, they should to wait until all stages of test in all instances had processed by Panselnas. And then result of the test would be released and launched by Minister of Administrative and Bureaucratic Reform coordinated with Panselnas. Besides, there a several positions in several instances who needed affirmative policy and also several local governments were late in collect result of the test to Panselnas. this case also made time to announce result of test was not accord within assumed time. And for this case government also had announced by official website for delaying of result processing to avoid negative reaction from candidates.

\section{Criteria of Effectiveness for Selection System}

Result of this research from all collected data was being compared and explained with theory of effectiveness of selection system by Rivai.

1) Accuracy

Before being announced as candidates who could follow the test, they should pass administrative test. Administrative criteria were different in each instance depends on positions and also instance itself. Commonly, candidates have to apply all requirements data such as graduated from accredited schools or universities, GPA, and English certificate (for specific instance). This rule to ensure quality of candidates were in good rate.

Basic Competency Test (TKD) which implemented to measure basic capability of candidates civil servants was considered to fulfill accuracy criteria. It can be seen from questions of TKD were made by a competent team from consortium several best state universities. Questions also were made for various graduated. Field competency test (TKB) also implemented for grab competent civil servants in specific and functional positions. Types of test were given to each involved instance, for example for nurse and midwife positions were handled by Ministry of health, teacher by Ministry of education and culture.
Despite, in measuring civil servants as product of this new system are not working completely. Because they were started to work in each instance just in July 2015. But some user argued that new civil servants had showed good performance in their work.

\section{2) Equality}

Equality was the most trend topic who discussed by several sides in central and local governments. Government was seen not compeletely fulfilled this aspect. Government should have taken affirmative policy involve registration procedure, it caused quality of internet network in developed area was not good as in advanced area. Equality also had involved within level of questions and passing grade which be inhibiting factor for local candidates with all limited facilities to improve their abilities.

In the other hand, Government had forced to adjust with condition in all areas. It can be seen how teacher competency test (UKG) for CAT who shared in all areas, could be used. It indicated that Government had considered all conditions, despite they were not accommodated all necessities.

\section{3) Trusty}

Level of trusty of a selection system can be seen by how selection system is acceptable and also gives benefit to all sides who involve in selection process. For committees as side of local and central governments, this CAT system was given several advantages. CAT system made instances could save their allocated fund. CAT system also made process of selection system more efficient. It caused almost all phases of CAT selection system were using advanced technology.

In the candidates side, This selection system given clarity about result of the test. Candidates could know directly a number of point that had reached. Thus, all candidates who passed and not passed the test trusted about the result. Despite time for announce the result was lated candidates still given good respon to wait it. Because Panselnas through Ministry of Administrative and Bureaucratic Reform official website had given explanation and information involves selection of civil servants.

CAT selection system in 2014 was also given good response from civils. It can be seen that Index of civils perception toward bureaucracy reform in 2014 was increased. In the first section of survey was from January-June 2014, index of perception reached 4.94 (less Good), while for next section from July-December showed that perception of civil reached 6.27, was means bureaucracy reform in adequate rate. Survey was conducted by Ministry of Administrative and Bureaucratic Reform in corporate within National survey agency. Survey was held in 12 cities that represented all areas in Indonesia. 


\section{Conclusion}

Based result of the research that had discussed within theory of effectiveness for selection system, there a number of conclusions of implementation of CAT selection system in local government areas, they were;

a. Despite there a few parts that be problem of this system such as in the registration phases, implementation of CAT selection system in local government areas can be said was working clearly. for registration problem, government had given solution as resolver. In other selection phases likes preparation, and implementation were working goodly. While for result processing despite it spent not short time, candidates had given an explanation and information through official website. Besides, competency of local residents also be another problem that failed sharply to pass the appointed passing grade in basic competency test (TKD) section.

b. This type of selection also can be said as an effective system. It caused, two of three aspects as criteria of effectiveness of selection system indicated that CAT system was in good rate. Accuracy and trusty were be the strengths of this system. Accuracy was mainly related with types of test, and trusty was related with satisfaction of candidates of this test that believe with result of test can be seen directly. Whereas for equality, it was not completely appropriate to represent this system. Equality was related with registration that used internet network that not shared perfectly in all Indonesian areas and ability of local residents in facing the test.

As more deep way of result of this research, few things were being suggested, they were:

a. CAT selection system was be encouragement way particularly in local governments to improve their work performance. Despite, several weaknesses occurred, advantages of this system was overweight to disadvantages. In surface implementation of CAT system in next years, Local government have to make prime preparation in all phases of test and make a good feedback as evaluation mechanism. Local government have to recognize that planning in determine of allocation for formation is a strategic phase. Workload analysis and position analysis also be made from a good calculation. In the phase of result processing, national committee have to verify the result completely, to avoid infringement. National committee also have to make a good technical direction, in order, all committees (Central and local) have good work mechanism. Implementation of CAT selection system also should followed by standard operating procedure (SOP) in all phases. Standard operating procedure has important function for make ensure all process working clearly, to avoid inefficient of time and to reduce misunderstanding in implemented this system.

b. Local governments within limited conditions should have to learn, evaluate, and change from implementation CAT selection system in 2014. The most thing that have to fix by local government is how to increase ability and competency of local residents. Main reason why a huge number of local governments denied this system was caused by under quality of local residents. Thus, through CAT system, competency of local residents could be measured. And also it could be consideration thing by local government to take a priority policy and fix this problem. Moreover, Infrastructure also be another thing that have to develop by local government. Despite this aspect also be central governments's responsibility. Infrastructure has important aspect to support all government activities. Furthermore, infrastructure is determines how a system will be working clearly. Similarly, CAT system could be measured capability of all infrastructures in local government. So local government could pay more attention in this aspect.

\section{REFERENCES}

Ahmadi, R. (2014). Metodologi Penelitian Kualitatif. Jakarta: Ar-Ruzz Media.

Aziz, A. (2015). Efektivitas Seleksi CPNS Berbasis Computer Assisted Test di Kementerian Pendayagunaan Aparatur Negara dan Reformasi Birokrasi (Undergraduate Thesis). Institut Pemerintahan Dalam Negeri (IPDN).

Government of Republic of Indonesia,. (2014). Law of the Republic of Indonesia No. 5 of 2014 about the State Civil Apparatus. Jakarta: Ministry of Law and Human Rights.

Hardiyanthi, S. (2011). Effectivenes of Implementation Computer Assisted Test (CAT) System in the Competency-Based Selection for Candidate Civil Servant at National Civil Servant (Undergraduate Thesis). Universitas Indonesia.

Kertapraja, E., Rasyidin, R., \& Ponijan,. (2012). Pemerintahan Daerah. Jakarta: Inner bekerjasama dengan Universitas Satyagama.

Marwansyah,. (2012). Manajemen Sumber Daya Manusia (2nd ed.). Bandung: CV. Alfabeta. 
Miles, M. (1994). Qualitative Data Analysis (2nd ed.). Thousand Oaks, CA: SAGE Publications.

Ministry of Administrative and Bureaucratic Reform,. (2012). Laporan Akuntabilitas Kinerja Instansi Pemerintah. Jakarta: Ministry of Administrative and Bureaucratic Reform.

Ministry of Administrative and Bureaucratic Reform,. (2013). Laporan Akuntabilitas Kinerja Instansi Pemerintah. Jakarta: Ministry of Administrative and Bureaucratic Reform.

Ministry of Administrative and Bureaucratic Reform,. (2014). Laporan Akuntabilitas Kinerja Pemerintah Deputi SDM. Jakarta: Ministry of Administrative and Bureaucratic Reform.

Ministry of Administrative and Bureaucratic Reform,. (2014). Regulation of Minister of Administrative and Bureaucratic Reform No. 17 of 2014 about Supplemental Allocation and Procurement Formation of Candidates for Civil Servants of 2014. Jakarta: Ministry of Administrative and Bureaucratic Reform.

Ministry of Administrative and Bureaucratic Reform,. (2014). Regulation of Minister of Administrative and Bureaucratic Reform No. 29 of 2014 about Threshold Limit Values Basic Competence Test Selection of Civil Servants of 2014. Jakarta: Ministry of Administrative and Bureaucratic Reform.

Ministry of Administrative and Bureaucratic Reform,. (2013). Profil Pendayagunaan Aparatur Negara. Jakarta: Ministry of Administrative and Bureaucratic Reform.

Ministry of Administrative and Bureaucratic Reform,. (2014). Public Perception Survey on Bureaucratic Reform. Jakarta: Ministry of Administrative and Bureaucratic Reform.

Mitrani, A., Dalziel, M., \& Fitt, D. (1992). Competency Based Human Resource Management. London: Kogan Page.

Mondy, R. (2008). Manajemen Sumber Daya Manusia Jilid 1 (10th ed.). Jakarta: Erlangga.

National Civil Agency (BKN),. (2014). Laporan Akuntabilitas Kinerja Instansi Pemerintah Badan Kepegawaian Negara. Jakarta: National Civil Agency (BKN).

National Civil Agency (BKN),. (2014). Regulation of Head of State Employment Agency No. 29 of 2014 about Standard Operating Procedure
Implementation of Basic Competency Test for Candidate Civil Servants of Public Applicants 2014. Jakarta: National Civil Agency (BKN).

Padang, J. (2015). Proses Pengadaan Calon Pegawai Negeri (CPNS) dengan Sistem Computer Assisted Test (CAT) di Kantor Badan Kepegawaian Daerah (BKD). eJournal Ilmu Administrasi Negara, 3(2).

Putri, A. (2015). Implementasi Seleksi CAT di Kabupaten Halmahera Barat (Undergraduate Thesis). Institut Pemerintahan Dalam Negeri (IPDN).

Pynes, J. (2009). Human Resources Management for Public and Nonprofit Organizations (3rd ed.). San Francisco, CA: Jossey-Bass.

Rees, D. \& McBain, R. (2007). People Management: Teori dan Strategi, Tantangan dan Peluang. Jakarta: Kencana Prenada Media.

Rivai, V. (2013). Manajemen Sumber Daya Manusia untuk Perusahaan. Jakarta: PT. Raja Grafindo.

Rubaii-Barrett, N. \& Wise, L. (2007). From Want Ads to Web Sites: What Diversity Messages Are State Governments Projecting?. Review of Public Personnel Administration, 27(1), 21-38. http:// dx.doi.org/10.1177/0734371x06289040

Silalahi, U. (2011). Asas-asas Manajemen. Bandung: Refika Aditama.

Suedy,. (2015). Implementasi Kebijakan Rekrutmen dan Seleksi Calon Pegawai Negeri Sipil: Studi pada Pemerintah Daerah DIY (Master Thesis). Universitas Gadjah Mada.

Sugiyono,. (2009). Metode Penelitian Kuantitatif, Kualitatif, dan R\&D. Bandung: CV. Alfabeta.

Wibowo, A. (2014). Analisis Kepuasan Pengguna Computer Assisted Test (CAT) Terhadap Pelaksanaan Seleksi Calon Aparatur Sipil Negara di Kantor Regional VIII Badan Kepegawaian Negara Banjarmasin (Undergraduate Thesis). Badan Kepegawaian Negara \& Universitas Terbuka.

Wulandari, F. \& Fanida, E. (2014). Implementasi Metode Computer Assisted Test (CAT) dalam Rekrutmen Calon Pegawai Negeri Sipil di Kantor Regional II Badan Kepegawaian Negara Surabaya. Jurnal Mahasiswa Teknologi Pendidikan, 2(3). 